RESEARCH ARTICLE

\title{
Awareness and Extent of Adoption of In-Situ Water Conservation (ISWC) Practices among Dryland Farmers
}

\author{
Vinotha, $\mathrm{T}^{\mathbf{1 *}}$., Mahandrakumar, $\mathrm{K}^{1}$., Anitha Pauline, $\mathrm{A}^{1}$ and Prabakaran, $\mathrm{K}^{2}$ \\ $1 *$ Department of Agricultural Extension and Rural Sociology, AC\&RI, Madurai-625104. \\ ${ }^{2}$ Department of Agricultural Economics, AC\&RI, Madurai-625104.
}

\begin{abstract}
The study was conducted among dry land farmers of Pudukkottai district in Tamil Nadu. Using random sampling method 80 respondents were selected and data was collected through pre-tested interview schedule. Adoption index was used to quantify the selected In-Situ Water Conservation (ISWC) practices. The study examined the level of awareness and extent of adoption of In-Situ Water Conservation (ISWC) practices among dry land farmers. The results showed that among the eight selected practices, respondents had cent percent awareness about summer plough, land leveling and ridges and furrows. Majority of respondents had medium level (76.20\%) of adoption of ISWC practices respectively. The study reveals that most of the respondents followed more than two ISWC practices on their farms to conserve the rainwater.
\end{abstract}

Keywords: ISWC; Dryland; Awareness; Adoption index

\section{INTRODUCTION}

Agriculture has an indelible place in the Indian economy. In India, dry land cultivated area accounts 68 per cent of the total net sown area (136.8M. Ha) (Vision-2030 CRIDA). Tamil Nadu held nearly $2 / 3$ of the cultivated area (66\%) under dry land condition (Department of Economics and Statistics 2019). In which the crops like pulses, cotton, gingelly and minor millets are cultivated predominantly. Here the most important problem with dry land is water scarcity particularly at the time of dry spells. This makes the framers to adopt In-Situ Water Conservation (ISWC) practices. Utilizing these ISWC practices to provide irrigation to crops and maintain the soil moisture (Relani et al., 2015 \& Balasaheb Devidas Romade, 2016). In recent days the government has implemented programs like Integrated Watershed Management Programme (IWMP), National Agricultural Development Programme/ Sub-mission on Agricultural Mechanization (NADP/ SAM), National Mission on Sustainable Agriculture (NMSA) and Tamil Nadu Mission on Sustainable Dry Land Agriculture (TNMSDA) in Pudukkottai district which are popularizing the ISWC practices (District Statistical Handbook 2017-2018). In this context, the study investigates awareness and the extent of the adoption of ISWC practices by dryland farmers.

\section{MATERIAL AND METHODS}

Description of study area

The study was conducted in two blocks of Pudukkottai district, namely Gandarvakotai and Thiruvarankulam. The two blocks were intentionally selected as the major area is under dryland farming. By quota sampling method, the respondents numbering 80 were selected and the farmers were chosen from the list of assistant director agriculture office to implement Mission on Sustainable Dry land Agriculture (MSDA) programme and ex-post facto research design was used.

\section{Method of Data collection \& Analysis}

Survey method, was used to collect primary data from the respondents through a well-constructed and pre-tested interview schedule. The collected data were analyzed through descriptive statistics and Karl Pearson's coefficient of correlation by using SPSS software.

\section{Adoption index}

Adoption Index was employed to quantify the selected dryland ISWC practices. The collected raw adoption scores were converted into an adoption index through the scoring procedure followed by Rajina Potsangbam (2018). Based on the adoption index (Al), the respondents were categorized into three i.e., low (upto 33.33), medium (33.33-66.66) and high (66.66-100). 
Adoption Index $=\frac{\text { Number of in }- \text { situ water conservation practices adopted by an individual }}{\text { Total number of ISWC practices taken for study }} \times 100$

\section{RESULTS AND DISCUSSION}

\section{Awareness and Adoption of ISWC practices among dry land farmers}

Figure 1, shows the cent percent of summer ploughing, land leveling and ridges \& furrows practices followed by compartmental bunding (98.75\%). Nearly two-thirds of the respondents were aware of farm pond (68.75\%), followed by broad bed furrows (58.75\%) practices. Very low level of awareness was observed in recharge pit (3.75\%) and trench cum bund (2.50\%) practices. None of the respondents practiced tied ridges as there was no awareness.

Figure 1. Distribution of respondents according to their awareness and adoption of ISWC practices

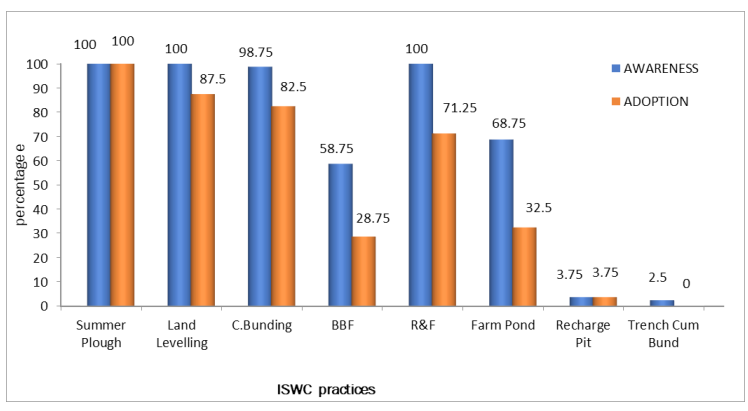

From Figure 1, it can be observed that cent percent of respondents pertaining dry land farming adopted summer plough followed by land leveling (87.50\%), compartmental bunding (82.50\%). Nearly about three- fourth of respondents adopted ridges \& furrows (71.25\%). Almost one-third of the respondents had adopted farm pond (32.50\%) followed by broad bed furrows (28.75\%). Recharge pit was adopted by only 3.75 per cent of the respondents. None of the respondents adopted trench cum bund and tied ridges.

Moreover, it was noted that there was less adoption of ISWC practices through they were well aware of those practices. In dry land, respondents, prefer to go for direct sowing on the ploughed land, which created an advantages of conserving the rainwater in the field, which serve as the reason for low adoption of land leveling. Fear of waterlogging in furrows during excess rainfall, additional cost involved in raising the furrows, unavailability of workers and lack of access to the farm machinery are the reasons for lower adoption of ridges \& furrows, broad bed furrows and compartmental bunding. Regarding farm pond, the respondents feared that such construction demand higher cost and they have to lose the portion of cultivable land at and the cumbersome procedure involved in getting subsidy provided by the government. Since, very few respondents were aware of trench cum bund, recharge pit and tied ridges, the adoption was also found to be low.

\section{Distribution of respondents according to number of practices adopted in their farm}

Figure 2, clearly showed that the majority of the dry land farmers adopted more than one In-Situ Water Conservation Practices in their farming land to conserve the rainwater. This result is in line with Anitha Pauline et al, (2020).

Figure 2. Distribution of respondents according to number of practices adopted in their farm

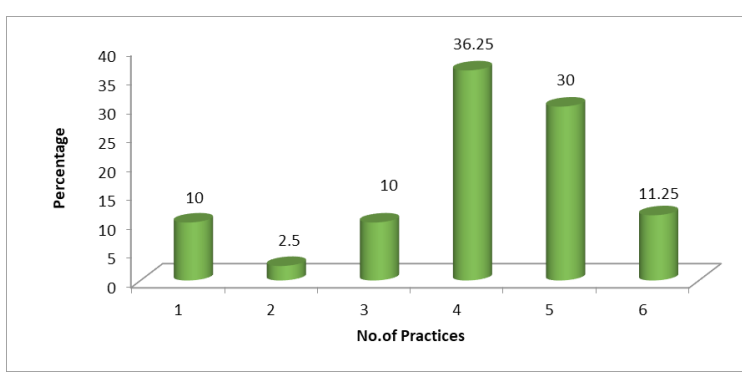

\section{Distribution of respondents according to Adoption index}

Table 1, revealed that the majority of the respondents in dryland farming had medium level of adoption (76.20\%) followed by low (12.50\%) and high (11.30\%) level of adoption. This trend revealed that respondents among dry land famers had an inclination to practice the in-situ water conservation practices.

Table 1. Distribution of respondents according to Adoption index

\begin{tabular}{lcc}
\hline \multicolumn{1}{c}{ Category } & $\begin{array}{c}\text { Frequency } \\
\mathbf{N = 8 0}\end{array}$ & Al \\
\hline Low (0-33.33) & 10 & 12.5 \\
Medium (33.33-66.66) & 61 & 76.2 \\
High (66.66-100.00) & 9 & 11.3 \\
\hline Mean: 45.28 & SD: 15.18 &
\end{tabular}

The findings of the study are similar to those of Jaganathan et al,. (2009) and Deepak Benat et al,. (2010) but contrast with Rajna potsangbam (2018).

\section{Relationship between the characteristics of dry land farmers and adoption of ISWC practices}

From Table 2, it is inferred that among the socio- personal variables, age had negative and educational status had positive association with the awareness and adoption of ISWC practices. This indicates that the farmers who belong to young age groups are eager in accepting and adopting

$107 \mid 10-12$ | 2 
ISWC practices because of their innovative and venturesome attitude. As education makes the farmers open-minded for new ideas, positive association was observed. Among the situational variables land holding and cropping intensity had positive and significant association with the ISWC practices. When an individual possess larger land holding, he will be able to devote some portion of land for ISWC practices like construction of farm pond, compartmental bunding, broad bed furrows etc., this positive association was observed. It is inevitable that farmers who are raising a number of crops in the same field during an agricultural year have to conserve the water to carry out the cultural practices in the ensuing dry season. Hence, cropping intensity has established positive association with the ISWC practices.

\section{Table 2. Relationship between the predictors of dry land farmers and adoption of ISWC practices}

\begin{tabular}{|c|c|c|}
\hline \multirow[t]{2}{*}{ Predictors } & \multicolumn{2}{|c|}{$\begin{array}{l}\text { Coefficient of } \\
\text { correlation (r) }\end{array}$} \\
\hline & Awareness & Adoption \\
\hline Age & $-.297^{* *}$ & $-.255^{*}$ \\
\hline Educational Status & $.526^{* *}$ & $.325^{* *}$ \\
\hline Family Size & $.001^{\mathrm{NS}}$ & $.024^{\mathrm{NS}}$ \\
\hline Land Holding & $.514^{* *}$ & $.461^{* *}$ \\
\hline Cropping Intensity & $.258^{*}$ & $.370^{* *}$ \\
\hline Occupation & $.022^{\mathrm{NS}}$ & $-.138^{N S}$ \\
\hline Annual Income & $.255^{*}$ & $.197^{\mathrm{NS}}$ \\
\hline Innovativeness & $.251^{*}$ & $.270^{*}$ \\
\hline Social Participation & $.173^{\text {NS }}$ & $0.177^{\mathrm{NS}}$ \\
\hline Information Seeking Behaviour & $.409^{* *}$ & $.431^{* *}$ \\
\hline Cosmopoliteness & $.422^{* *}$ & $.269^{*}$ \\
\hline Risk Orientation & $.249^{*}$ & $.268^{*}$ \\
\hline Economic Motivation & $.261^{*}$ & $.283^{*}$ \\
\hline Scientific Orientation & $.235^{*}$ & $.210^{\mathrm{NS}}$ \\
\hline Awareness of Soil Erosion problem & $.364^{* *}$ & $.318^{* *}$ \\
\hline Accessibility to Farm Implement & $.293^{* *}$ & $.383^{* *}$ \\
\hline
\end{tabular}

*. Correlation is significant at the 0.05 level

The psychological traits like innovativeness, information seeking behaviour, cosmopoliteness, risk orientation and economic motivation had a significant and positive relationship with awareness and adoption of ISWC practices. It is natural that the farmer who is having a mental frame of trying to follow recent technologies used to seeks a lot of information not only from local but also from cosmopolite sources, which could have resulted in the positive association of these variables with awareness and adoption. Similarly, an individual who focused upon earning more income necessarily takes some risk in adopting scientific innovation might be the reason that these variables have a positive association with awareness and adoption of ISWC practices. Those farmers who are well aware of the damage caused by soil erosion and who have good access to the farm implements could adopt the ISWC practices.

\section{CONCLUSION}

From the above results, the majority of the dry land farmers had a medium level of adoption showing that the respondents have the inclination to practice ISWC practices. Hence, dry land farmers need to be educated and have to be exposed to various dry land water conservation practices by the officials of the state department of agriculture and engineering.

Adoption of ISWC practices had positively associated with education, land holding, information seeking behavoiur, cropping intensity, awareness of soil erosion problems, accessibility to farm implements, innovativeness, cosmopoliteness, risk orientation and economic motivation. Age has significant but negative association with adoption. These variables should be taken into account to determine a strategy to reach the farmers.

In general, farmers in the study area were not well aware of recent soil and water conservation programs like Tamil Nadu Mission on Sustainable Dry land Agriculture (TNMSDA), National Mission on Sustainable Agriculture (NMSA), Kudimaramathu scheme etc. To rectify this defect intensive campaign through a mobile van depicting the particulars related to the scheme may be arranged.

\section{REFERENCES}

Anitha Pauline, A., Mahandrakumar, K. and C.Karthikeyan. 2020. Adoption of Rain Water Harvesting Structures in Dryland Areas of Tamil Nadu, India. Int. J.Curr. Microbiol.App.Sci., 9(3):3271-3278.

Balasaheb Devidas Romade. 2016. Constraints in adoption of dryland technologies. MSc Thesis. Mahatma phule krishi vidyapeeth, RahuriMaharashrtra state (India).

Deepak Benal., Patel, M.M., Jain, M.P. and V.B. Singh. 2010. Adoption of Dryland Technology. Indian Journal of Dryland Agricultural Research and Development., 25(1): 111-116.

Jaganathan,D., Padmanabham, V.B., Bhaskaran., Chandru, A. and B. Johnson. 2009. Adoption of Organic Farming Pactices by vegetable growers. Indian Journal of Extension Education., 45: 21-24.

Rajina Potsangbam., Kale, N.M and N.P. Jangwad.2018. Knowledge and adoption of Brinjal growers about recommended cultivation practices in Akola district. Int. J Humanit Soc Sci., 7(4):183-188.

Rejani, R., Rao, K.V., Osman, M., Chary, G.R., Pushpanjali, Sammi Reddy, K and C.H. Srinivasa Rao.2015. Location specific in-situ soil and water conservation interventions for sustainable management of drylands. J. Agrometeorol., 17(1):55-60. 